\title{
Research on autonomous learning methods in the ideologi- cal and political education of universities
}

\author{
Yuan Zhao \\ Social Science Department \\ Hebei Finance University \\ Baoding,China
}

\author{
Wen-yu Xin \\ Research Office \\ Hebei Finance University \\ Baoding,China
}

\author{
Lian Liu \\ Xianfeng School \\ Baoding,China
}

\begin{abstract}
In recent years, with the rapid development of society and the deepening of education reform, the ideological and political education is more and more attention. Education courses in colleges and universities is the main channel of ideological and political education of college students, college students' autonomous learning is an important platform, in this paper, the difficulties facing education courses in colleges and universities and the trend of college students' autonomous learning ability weakened, talk about how to take the student as under the guidance of this concept, explore the application of autonomous learning in education courses, to enhance the efficiency of the education courses.
\end{abstract}

Keywords: Autonomous Learning; Education Courses; Penetration and Fusion

\section{INTRODUCTION}

Ideological and political education as a basic project of socialist spiritual civilization, the socialist modernization construction and education of colleges and universities plays a vital role. The ideological and political education is an important aspect of human social practice. It is a society or social groups with certain ideas, political views, and ethics, to its member purposeful, planned and organized. It eventually makes them form accord with certain social or need a certain class ideology and moral character of social practice. In our country, the educations of ideological and political education not only have their own independent system, more important is that it has the important task. With Marxism-Leninism, MAO Zedong thought, Deng Xiaoping theory education of the masses of the people. Ideological education aims to cultivate and bring up with ideal, morality, culture and discipline of socialist new people. However, with the rapid development of economic globalization, the social public to the ideological and political education work puts forward higher requirements and goals. The ancients cloud: "sending their fish only will be needed for a meal; teach to fish, lifelong many times." The famous American psy- chologist and educationist Bruner proposed: "finding not only limited to seek unknown things, human right, it includes knowledge in our heads all the way." The best way to learn any knowledge is to find, because this most found that understanding is the most easy to grasp the rule. As a teacher, we teach students not only knowledge, more important is teaching students the way of learning. Therefore, changing the traditional teaching idea, follow the rules of education, autonomous learning teaching methods, to mobilize students' learning initiative and enthusiasm, to enhance the actual effect of ideological and political theory class teaching.

\section{The meaning of autonomous learning}

Teacher, who is preaching, spreads knowledge and reassure the questions. Traditional way of teaching in teachers' teaching is given priority to; students seldom have the chance to put forward original ideas, devoid of the students' creative play. Autonomous learning is an effective way to break the current teaching methods single. Autonomous learning is a kind of study way in advance. It is to point to in the classroom, teaching subject before the learning activities to be able to determine the learning objectives, learning plan, ready for the concrete study. It ordered that the students in the learning activities can progress in learning and learning methods to self-monitoring and selfregulation. Hope students after learning activities can result in learning self-examination and self-summary, selfassessment. This is a kind of by the learners' attitude, ability and learning strategies factors such as comprehensive and become a leading the intrinsic mechanism of learning.

Education courses of autonomous learning is to embody the subject status of students in teaching, strictly follow the rules of education, guide the students to study actively, from passive learning to active learning. This is the new century new stage our country education concept of a fundamental shift. 


\section{The necessity of cultivating universities students' au- tonomous learning ability}

Education courses in colleges and universities in the CPC central committee, under the loving care of sticking to the Marxism theory education to college students' system of the main channel and position. But at present, indisputable fact of the low education courses is teaching effectiveness. Throughout the current status of college students' education courses to learn, let us not optimistic. Undergraduate colleges and vocational colleges, students of education courses on the common understanding deviation, think some redundant, passive learning attitude. Classroom teaches content boring, rigid, lack of interactive learning, discussion, and social practice, a far cry from their professional prospects. It is difficult to grasp the students' learning psychology, hard to accept. Therefore, change the traditional teaching mode, guides the student to participate in classroom teaching, cultivate students' autonomous learning ability is very necessary. Cultivating students' autonomous learning ability is to adapt to the needs of the development of society, is necessary for the reform of college education courses, it helps to enhance the effect of education courses "education", is to focus on students' life value, an effective way to cultivate students' comprehensive quality.

Education courses in colleges and universities teaching is a main position and main channel of ideological education for college students, guide students to learn and inheriting Marxism theory, to enhance the Marxism connotation of education courses, to the construction of socialist theory with Chinese characteristics in the new period and the construction of the socialist core value system, has important realistic significance and far-reaching historical significance.

\section{Methods about cultivating students' autonomous learning ability}

Changing the traditional teaching idea, follow the rules of education, autonomous learning teaching methods, to mobilize students' learning initiative and enthusiasm, to enhance the actual effect of ideological and political theory class teaching.

\subsection{To help college students set up the correct learning attitude}

Guide the contemporary college students' focus on self, pay attention to society, to enhance the social sense of responsibility, is one of the mission of education courses in colleges and universities. In recent years of teaching, I've been trying to use ten minutes before class time for students to broadcast a week since the major international and domestic news and campus news, and then reviews shall be conducted by the teacher. Students participate in the enthusiasm is very high, they volunteer group, make full use of, reasonable division of labor, using collection and screening of their spare time surfing the Internet news information, download pictures and short video, making courseware, students have volunteered to power on presentation. Through this process of autonomous learning, students shall understand the news this week, to enhance the social sense of responsibility, and exercise the students' ability of collecting information, language expression ability, team cooperation consciousness, etc., improve the comprehensive quality of students.

In recent years, with the development of the society, some college students influenced by the social bad style, coupled with the lack of good discrimination analysis ability, often like to ponder the question from the negative things, easy to go to extremes. Part of the college students think that the ideological and political theory class is talking about the socalled "truth", "false, big and empty" is their opinion of the course. Besides, now a part of the college students, people more impetuous, quick success, only keen for professional course study during the university, and for public basic course is completely in order to complete the credits and learning, to education courses learning is necessary. Therefore, to make college students realize the importance of learning education courses, on the first ideological theory course is full description: through the positive and negative examples of the ascension of our quality (of course including education literacy) in one's life is how important. In addition, in the daily study, also should be paid attention to on the basis of learning theory knowledge, teach them the correct analysis of some existing in the current social phenomenon, so that they gradually learn to use what they have learned theoretical knowledge analysis and deal with the things around, really put this to use, feel the ideological and political theory in practice guidance, change their commitment to the course "false, big and empty "bad impression, and consciously to set up a good learning attitude.

\subsection{To strengthen the cultivation of college students' social mission}

After 30 years of reform and opening up, in the 21st century, a very important task is to realize the great rejuvenation of the Chinese nation, a glorious task for every Chinese people strive for, especially the college students as the main builder motherland in the future. Through years of traditional education, the vast majority of college students has been think "technology devotion, serving the people wholeheartedly", and for the people "do one" best, even every communist party member, especially leading cadres should be done. Realize national rejuvenation is their glorious duty. Social reality often let them hear and see some negative phenomenon, a small number of party members and cadres, there is no real learning comprehend Marxist theory, lost the communist ideal and faith, moral decay, even become a member of the corrupt. To make matters worse, the society has many people used to spread even exaggerate the bad things, on the contrary, but not good things timely propa- 
ganda, so part of the college students to form the bad habits, see a problem more extreme and social mission.

Some college students lose should have confidence in ideological and political education, even for highly suspicious of education in the past., therefore, must let them know, in every society has both good side and bad side, before humans into the communist society, is not possible for us to make every thought state established height, even is the communist party member. At this time, make the students learn to see things objectively is especially important are these corrupt officials, bad phenomenon, investigate its reason, is that they neglect to the study of the theory of Marxism, ignore to arm themselves with Marxism's mind. So college students should take on social efforts to study the phenomena of these bad to his Marxist basic theory of the power, make one become the main force of national rejuvenation in the future. With such a social mission, we will have autonomy in education courses of study.

\subsection{Using a variety of teaching means and methods, inspire students' interest in learning}

The traditional way of teaching are mainly composed of teachers teaching. With the development of science and technology, many use multimedia teaching equipment in modern teaching, on the basis of teachers fully preparation, combined with the use of various teaching contents related film and video data, can let the student to contact more image, more intuitive way knowledge, and teaching effect is enhanced. But autonomy learning in college students didn't get much improvement. Therefore, must work in the teaching methods. Specifically, we can follow the following several aspects.

\section{- List more justice}

In real life, many students of the capitalist world socialistic often like to use their own weaknesses to compare and strengths of the developed capitalist countries. For the state, society, due to expect too much of a lot of places are demanding, true have a little "in" bliss. According to the American psychologist Roy Boo, such as research, the influence of bad things to human is bigger than the influence of the good things, this is a normal psychological, is called "negative bias". That is to say, people will be more attention to negative information and events. In fact, in our country has a lot of good things than capitalism society, the key is willing to go to find.

In the annual national moral model awards, we all be moved to tears! Only focus on more justice, can have a normal mentality, and to consistently positive energy. Only when the students thought political education theory class teaching knowledge in socialist do play a powerful role in talent training, learning education theory will consciously and actively.

\section{- Classroom discussion}

Now great changes have taken place in college students living environment, also appears relatively independent in many things. Therefore, the teacher in the classroom of avoid by all means "them", and should try some hot issues on the teaching content and the current social link, lets the student in class groups communicate, discuss, and choose on behalf of the team's point of view. In view of the different point of view, by the students for their views fully reasons can even to debate. Finally, we made by teacher explained clearly, in order to eliminate students' heart doubts. Practice has proved that this kind of learning method to strengthen the cultivation of the students' ability to integrate theory with practice also is in the college students' autonomous learning is one of effective methods.

- Make theme PPT by themselves

In daily teaching, can choose a part of the teaching material content, let the students work in on the basis of the teaching material, mainly on their understanding of the textbook knowledge to make the theme PPT, and then in the classroom, and then let the whole class to ask questions, making PPT team members questions mainly around the content of the PPT, make the teaching material content between question and answer in the minds of the students deepen impression, effect is much better than the traditional mode of operation. Because the operation of the entire process, if there is no students' autonomous learning is difficult to complete. It's also one of the college students' autonomous learning good.

\section{Conclusion}

College students' education courses use in promoting the course of learning autonomy learning plays a very important role. In the daily teaching process to this kind of autonomous learning and apply it well, in addition to the above several aspects, in teaching practice to explore a new better method, make students form the good habit of independent learning for use, so as to achieve the aim of improve college students' ideological theory course learning effect.

\section{References}

[1] Yangxiang Deng. "The application of autonomous learning in college students' education courses," Journal of Kaifeng Institute of Education,pp. 101-102, 2014 .

[2] Hailin Qiao, "Innovation and development of the theory of ideological and political education management," Journal of Henan Normal University, pp. 57-60,2007

[3] Jianxin Hua," The characteristics of autonomous learning and learning methods," China Distance Education Journal,pp. 35$-37,2001$.

[4] Xiangjun Liu," To analysis the autonomy of the ideological and theoretical study," Journal of Henan Institute of Science and Technology, pp.89-92,2012.

[5] Yongchun Wang," Contemporary college students' political socialization and political education in colleges and universities education method innovation," Education Management, pp. 240-241,2015. 